\title{
Morphological and genetic confirmation of extensive distri- bution of a pelagic polychaete Poeobius meseres Heath, 1930 (Annelida Flabelligeridae)
}

\author{
Naoto Jimi ${ }^{*}$,AtsushiYamaguchi ${ }^{2} \&$ Yoshihiro Fujiwara ${ }^{3}$ \\ ${ }^{1}$ Biosciencegroup, National Institute of Polar Biology, 10-3 Midoricho, Tachikawa, 190-0014, Japan \\ ${ }^{2}$ Graduate School of Fisheries Sciences, Hokkaido University, 3-1-1 Minato, Hakodate, Hokkaido, 041-0821, Japan \\ ${ }^{3}$ Marine Biodiversity and Environmental Assessment Research Center, JAMSTEC, 2-15 Natsushima, Yokosuka, Kanagawa, \\ 237-0061, Japan \\ *Corresponding author, email: beniimo7010@gmail.com
}

\begin{abstract}
A pelagic polychaete, Poeobius meseres Heath, 1930 (Anellida Flabelligeridae), is mainly known from California, Northeast Pacific, and is well studied in the region. However, little is known from Northwest Pacific, which is needed for understanding its biodiversity and accurate distribution. We report morphological and genetic data of this species collected off Tohoku, Japan and off the Aleutian Islands, USA, and confirm ITS extensive distribution (over $4000 \mathrm{~km}$ ).
\end{abstract}

KEY WORDS

Aleutian Islands; pelagic; Polychaeta; polychaetes.

Received 21.04.2019; accepted 19.06.2019; published online 11.12.2019

\section{INTRODUCTION}

Pelagic polychaetes often have wide-range distribution due to their pelagic habits (Dales \& Peter, 1972). However, their distributional pattern is not well clarified due to the difficulty of sampling across several countries for covering broad distribution. Further information on their distribution is needed for understanding their life cycle and biogeography.

A pelagic polychaete genus, Poeobius Heath, 1930 , is unique in its morphology, i.e., it lacks segmentation/chaetae and was classified as Poeobiidae that was thought to be the key for understanding the connectivity between polychaetes and echiurans (Heath, 1930). Recent molecular phylogenetic analyses showed that this genus is contained in Flabelligeridae (Burnette et al., 2005; Osborn \& Rouse 2008, 2010). Poeobius meseres Heath, 1930 is the sole species of Poeobius and is distributed in the $\mathrm{Pa}$ cific Ocean (Heath, 1930; McGown, 1960; SalazarVallejo, 2008). Recently, an undescribed species of Poeobius was found in the Atlantic Ocean (Christiansen et al., 2018). Poeobius meseres was reported mainly from Northeast Pacific (Salazar-Vallejo, 2008). However, some of the papers indicated that the species is also present in Northwest Pacific and Southeast Pacific (Yamada, 1954; McGown, 1960). Salazar-Vallejo (2008) reviewed specimens of $P$. meseres collected from Northeast Pacific and concluded there are at least two morphotypes in this species. Salazar-Vallejo (2008) also mentioned "some other records in the Western Pacific and in subtropical localities should be confirmed" for a better understanding of Poeobius diversity. Although there are records by McGown (1960) of P. meseres from Japanese waters, the paper did not provide any morphological and genetic data, and thus, we could 
not infer that the distribution record consists of one or more species in Pan-North Pacific. Morphological information accompanied with its genetic data are needed for understanding of the biodiversity and distribution of Poeobius species. In this study, we report $P$. meseres collected from Aleutian and Japanese waters with morphological and genetic confirmation.

\section{MATERIAL AND METHODS}

Sampling from two localities: i) Vertical Multiple Plankton Sampler (VMPS) was applied on 6 August 2017, three specimens were collected from 750-1000 meters of depth, off Aleutian Islands $\left(54^{\circ} 17.7229^{\prime} \mathrm{N}, 166^{\circ} 23.7795^{\prime} \mathrm{W}\right)$, USA, during the MR17-04 cruise by R/V Mirai; ii) ROV Hyper-Dolphin was operated on 9 October 2013, one specimen was collected from 433 meters of depth, off Sanriku (39³6.984' N, $142^{\circ} 15.543^{\prime}$ E), Japan, during the NT 13-21 cruise by R/V Natsushima. All the specimens were fixed and preserved in $70 \%$ ethanol. The preserved specimens were observed under stereoscopic microscopes (Nikon SMZ1500 and OLYMPUS BX51); photographs were taken using a digital camera (Nikon D5200). Voucher specimens were deposited in the JAMSTEC (No. JAMSTEC-1170056154 and 1130040972). DNA extraction, sequencing, and phylogenetic analysis were conducted by use of cytochrome c oxidase subunit I (COI) following the method of Jimi \& Fujiwara (2016). The genetic distance was calculated following Jimi \& Fujiwara (2016). Newly obtained sequences have been deposited in the DNA Data Bank of Japan (DDBJ): DDBJ No. LC508300 (Aleutian), No. LC508299 (Japan). Additional COI sequences of Poeobius meseres from California and Trophoniella hephaistos from Japan as an outgroup were obtained from GenBank (GenBank No. EU694130 and LC136932) (Osborn \& Rouse 2008; Jimi \& Fujiwara 2016). COI gene of Daylithos sp., another member of the outgroup, was sequenced and deposited in DDBJ (DDBJ No. LC508301.

\section{RESULTS}

\section{Systematics}

Phylum ANNELIDA Lamarck, 1809
Classis POLYCHAETA Grube, 1850

Ordo TEREBELLIDA sensu Rouse et Fauchald, 1997

Familia FLABELLIGERIDAE Saint-Joseph, 1894

Genus Poeobius Heath, 1930

\section{Poeobius meseres Heath, 1930}

EXAMINED MATERIAL. JAMSTEC 1170056154, three specimens, off Aleutian Islands, USA, collected by Naoto Jimi and Atsushi Yamaguchi, $6 \mathrm{Au}-$ gust 2017. JAMSTEC 1130040972, one specimen, off Sanriku, Japan, collected by Yoshihiro Fujiwara, 9 October 2013.

DESCRIPTION. Body cylindrical, tapered in anterior and posterior region, cuticle thick, transparent in life and after preservation (Fig. 1). Body surface without papillae and sands. Eyes absent. Palps same length with branchiae or slightly shorter. Branchiae cirriform, arranged in a continuous dorsal series, ten in number. Single nephridial lobe present, placed close to the branchial filaments. Cephalic cage absent. Parapodia absent. Chaetae absent. Black eggs contained in the body. Pelagic.

Molecular AnAlisyses. In the resulting tree, specimens from the Japan and Aleutian Islands formed a clade (Bootstrap [BS] value: $100 \%$ ) (Fig. 2 ). They differed 0.02 in terms of the K2P distance. The specimen from the California is sister to Japan/Aleutian clade, with high BS value (100\%). They differed $0.055-0.057$ in terms of the K2P distances.

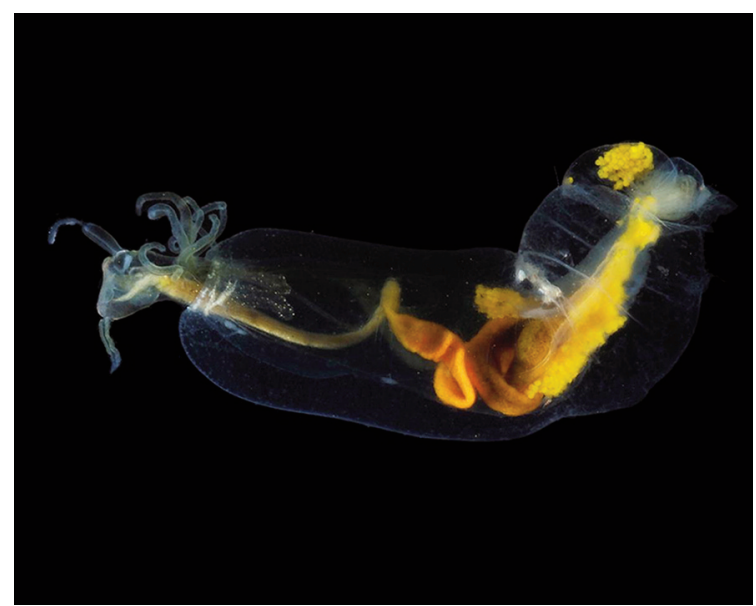

Figure 1. A live specimen of Poeobius meseres from off the Aleutian Islands. 


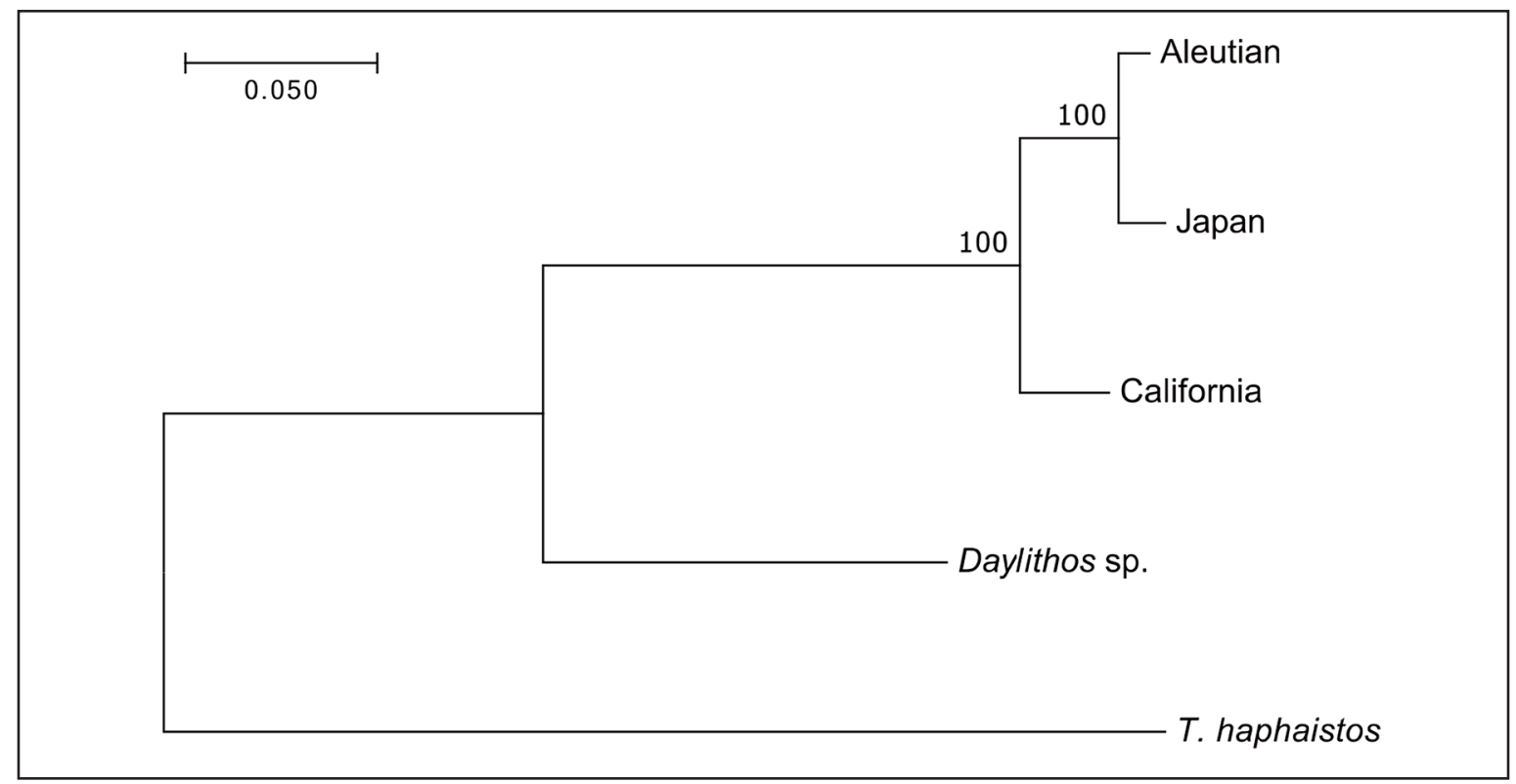

Figure 2. ML tree of Poeobius messers from off Japan, off the Aleutian Islands, off California based on COI gene sequences. Trophoniella hephaistos and Daylithos sp. are used as an outgroup. Numbers indicate bootstrap nodal support values.

\section{DISCUSSION}

In morphological observation (Fig. 1), the $P$. meseres specimens have the following features as reported in previous studies (Salazar-Vallejo, 2008): i) body depressed without segmentation, parapodia or chaetae, ii) transparent cuticle, iii), the presence of branchiae and nephridial lobe, iv) pelagic. Other features completely align with the previous genus diagnosis. In genetic analysis, Aleutian and Japanese specimens form a monophyletic clade (Fig. 2). The genetic K2P distance between Aleutian-Japan was 0.02 . On the bases of the morphological identity between Japanese and Aleutian individuals, this genetic distance seems to be intraspecific variations. On the other hand, between Aleutian/Japan-California there were 0.055 0.057 . There is no conclusive proof that this genetic distance is intraspecific variation because detailed morphology of the Californian specimen used for the molecular analysis was not shown. According to the description of Salazar-Vallejo (2008), Poeobius meseres contained at least two morphological variations. Our specimens are identical with one of the morphological variations in the following features: i) single nephridial lobe; ii)
10 branchiae; iii) branchiae are the same length or slightly longer than palps. However, there is no information on the features from the Californian individuals used for the molecular analysis. Genetic connectivity between individuals collected from Japanese and Californian waters is not discussed due to the lack of genetic information. More sequences with morphological data are needed for understanding of the Pan-North Pacific connectivity of this species.

Recently, studies about their "cosmopolitan" nature revealed the limited distribution of the polychaete species in a certain area (Hatchings \& Kupriyanova, 2018). Pelagic polychaetes have been thought to be cosmopolitan based on morphological analysis, but the genetic confirmation is critical for understanding their accurate distribution. Our morphological and genetic data support extensive distribution (about $4000 \mathrm{~km}$ ) of the pelagic species.

\section{ACKNOWLEDGENENTS}

We thank the crews of the R/V Mirai and Natsushima, scientific members of the cruise MR 17- 
04 and NT 13-21 for them help in the sampling. This study is partly supported by JSPS KAKENHI No. JP17J05066 to NJ.

\section{REFERENCES}

Burnett A.B., Struck T.H. \& Halanych K.M., 2005. Holopelagic Poeobius meseres ("Poeobiidae" Annelida) is derived from benthic Flabelligerid worms. Biological Bulletin, 208: 213-220.

Christiansen S., Hoving H-J., Schütte F., Hauss H., Karstensen J., Körtzinger A., Schröder S.M., Stemmann L., Christansen B., Picheral M., Brandt P., Robinson B., Koch R. \& Kiko R., 2018. Particulate matter flux interception in oceanic mesoscale eddies by the polychaete Poeobius sp. Limnology and Oceanography, 63: 2093-2109. https://doi.org/10. 1002/lno.10926

Dales R.P. \& Peter G., 1972. A synopsis of the pelagic Polychaeta. Journal of Natural History, 6: 55-92.

Drake P. \& Arias A.M., 1997. The effect of aquaculture practices on the benthic macroinvertebrate community of a lagoon system in the Bay of Cadiz (southwestern Spain). Estuaries, 20: 677-688.

Heath H., 1930. A connecting link between the Annelida and the Echinoidea (Gephyrea Armata). Journal of Morphology and Physiology, 49: 223-244.

Hutchings P. \& Kupriyanova E., 2018. Cosmopolitan polychaetes - fact or fiction? Personal and historical perspective. Invertebrate Systematics, 32: 1-9. http:// dx.doi.org/10.1071/IS17035

Jimi N. \& Fujiwara Y., 2016. New species of Trophoniella from Shimoda, Japan. ZooKeys, 614: 113. http://dx.doi.org/10.3897/zookeys.614.8346

Jimi N., Tanaka M. \& Fujiwara Y., 2016. Diplocirrus nicolaji (Annelida: Flabelligeridae) from Japan, detailed morphological observation and DNA barcoding. Marine Biodiversity Records, 9: 22. http://dx. doi.org/110.1186/s41200-016-0024-7

McGown J.A., 1960. The relationship of the distribution of the planktonic worm, Poebius meseres Heath, to the water masses of the North Pacific. Deep-sea Research, 6: 125-139.

Osborn K.J. \& Rouse G.W., 2008. Multiple origins of pelagicism within Flabelligeridae (Annelida). Molecular Phylogenetics and Evolution, 49: 386-392.

Osborn K.J. \& Rouse G.W., 2010. Phylogenetics of Acrocirridae and Flabelligeridae (Cirratuliformia, Annelida). Zoologica Scripta, 40: 204-219. https://doi.org/ 10.1111/j.1463-6409.2010.00460.x

Salazar-Vallejo S.I., 2008. Review of Poeobius meseres Heath, 1930 (Polychaeta: Flabelligeridae). Cahires de Biologie Marine, 49: 191-200.

Yamada M., 1954. Notes on Poeobius meseres Heath from the North Pacific. Doubutsugaku Zasshi, 63: 370-372. 